Yuichi Uwai · Satohiro Masuda $\cdot$ Maki Goto

Hideyuki Motohashi · Hideyuki Saito

Masahiro Okuda $\cdot$ Eijirou Nakamura $\cdot$ Noriyuki Ito

Osamu Ogawa $\cdot$ Ken-ichi Inui

\title{
Common single nucleotide polymorphisms of the MDR1 gene have no influence on its mRNA expression level of normal kidney cortex and renal cell carcinoma in Japanese nephrectomized patients
}

Received: 28 July 2003/ Accepted: 28 October 2003/Published online: 18 December 2003

(C) The Japan Society of Human Genetics and Springer-Verlag 2003

\begin{abstract}
In this study, we have quantified the mRNA expression levels of multidrug resistance gene 1 (MDR1) in the normal kidney cortex and renal cell carcinoma (RCC) segments from 24 Japanese nephrectomized patients by real-time polymerase chain reaction (PCR). The mRNA expression level of MDR1 in RCC segments was significantly decreased in comparison with each normal segment $(P=0.0042$, by Student's paired $t$-test). In addition, the ten common single nucleotide polymorphisms (SNPs) of the MDRl gene in the patients were assessed using the PCR-restriction enzyme fragment length polymorphism method to investigate the influence of these SNPs on its mRNA expression levels. The allele frequencies of these SNPs were comparable with our previous report in the Japanese recipients of living-donor liver transplantation (Goto et al., Pharmacogenetics 12:451-457; 2002). MDR1 expression levels in the normal kidney cortex were independent on the five SNPs, which were polymorphic in the Japanese population. Furthermore, the effect of the SNPs on expression levels of MDR1 mRNA in RCC segments was not recognized. These findings suggest that the common SNPs in the MDRl gene have no influence on the expression of its transcript in RCC segments as well as in the normal kidney cortex.
\end{abstract}

Keywords MDR1 1 SNP $\cdot$ Kidney $\cdot$ Renal cell carcinoma

\footnotetext{
Y. Uwai $\cdot$ S. Masuda $\cdot$ M. Goto $\cdot$ H. Motohashi $\cdot$ H. Saito M. Okuda $\cdot$ K. Inui $(\bowtie)$

Department of Pharmacy, Kyoto University Hospital, Sakyo-ku, Kyoto 606-8507, Japan

E-mail: inui@kuhp.kyoto-u.ac.jp

Tel.: + 81-75-7513577

Fax: $+81-75-7514207$

E. Nakamura $\cdot$ N. Ito $\cdot$ O. Ogawa

Department of Urology, Graduate School of Medicine,

Kyoto University, Kyoto, Japan
}

\section{Introduction}

An ATP-driven efflux pump P-glycoprotein (Pgp), the multidrug resistance 1 (MDR1 or $A B C B 1$ ) gene product, is expressed in the plasma membrane of several tumor and normal cells and mediates extrusion of endogenous compounds, xenobiotics and drugs including anticancer drugs, cardiac glycosides, immunosuppressants, and anthracycline antibiotics (Ambudkar et al. 1999). Besides Pgp one of component molecules for the multidrug resistance of tumor cells, the transporter is now accepted as playing an important role for intestinal absorption, tissue distribution, and biliary or urinary excretion of drugs in normal tissues (Ambudkar et al. 1999).

Single nucleotide polymorphisms (SNPs) exist in the $M D R 1$ gene, and the relationship between SNPs and the expression/function of MDR1 has been reported by several laboratories. First, Hoffmeyer et al. (2000) represented that the C3435T SNP in the MDRl gene influenced the expression level of Pgp in the duodenum and that the absorption rate of orally administered digoxin was dependent on the SNP in healthy Caucasians. However, following examinations comparing SNPs in the MDRl gene with drug absorption and/or the intestinal expression level of Pgp, MDR1 have not been reproducible (Kim et al. 2001; Kurata et al. 2002; Goto et al. 2002; Gerloff et al. 2002). Recently, Siegsmund et al. (2002) demonstrated that the allele T of cDNA 3435 in the MDRI gene reduced Pgp expression in the kidney. However, there are few reports illustrating in detail the renal MDR1 expression with influences by its genetic variations.

Renal malignant tumors account for more than $2 \%$ of cancer incidence, and renal cell carcinoma (RCC) compose the majority in renal tumors. RCC shows resistance against chemotherapy (Hartmann and Bokemeyer 1999), and it is suggested that Pgp is involved in the chemoresistance of RCC (Fojo et al. 1987; Kakehi et al. 1988). Siegsmund et al. (2002) also suggested that 
the C3435T SNP in the MDR1 gene would be a risk factor for the development of RCC in Caucasians. In spite of suggesting the significance of Pgp and/or MDRI SNPs on the patients with RCC described above, the role of Pgp for chemoresistance of RCC has remained to be elucidated.

In the present study, we quantified the mRNA levels of MDR1 in the normal kidney cortex and RCC segments from Japanese nephrectomized patients with renal tumors. In addition, the ten common SNPs of the MDRl gene in these patients were examined, and the association between genotypes and expression level was assessed.

\section{Materials and methods}

Patients

Twenty-four Japanese patients who were surgically nephrectomized with RCC at Kyoto University Hospital were enrolled in this study. The subjects consisted of 18 men and six women whose ages ranged from 39 to $74(63.6 \pm 8.5$, mean $\pm \mathrm{SD})$ years. The nephrectomized segments of the normal cortex and RCC were obtained after receiving written informed consent. The study was performed in accordance with the Declaration of Helsinki and its amendments, and was approved by the Ethics Committee of Kyoto University Graduate School and Faculty of Medicine.

\section{Isolation of total RNA and genomic DNA}

Total RNA and genomic DNA from a renal homogenate in a guanidinium thiocyanate solution were isolated with a MagNA Pure LC RNA isolation kit II and DNA isolation kit (Roche Diagnostic GmbH, Mannheim, Germany), respectively, as previously described (Goto et al. 2002; Motohashi et al. 2002). The isolated total RNA was reverse-transcribed, and the single stranded DNA was used for quantification of MDR1 mRNA levels. Genotyping of the $M D R l$ gene was performed using genomic DNA.

Quantification of MDR1 mRNA expression levels

MDR1 mRNA levels in the normal kidney cortex and RCC segments were measured by real-time polymerase chain reaction (PCR), as previously described (Motohashi et al. 2002). The primer/probe set for the specific amplification of MDR1 was designed according to parameters incorporated in the Primer Express software (PE Biosystems, Foster City, CA, USA). The forward and reverse primers were GCTCAGACAGGATGTGAGTTGGT (position; 2812-2834, accession number M14758 in GenBank database) and CCTGGAACCTATAGCCCCTTTAAC (position; 2897-2920), respectively. The sequence of TaqMan probe was AAAAACACCACTGGAGCATTGACTACCAGG, corresponding to the position 2846-2875. Real-time PCR was performed in a total volume of $20 \mu \mathrm{l}$ containing $2 \mu \mathrm{l}$ of reverse-transcribed cDNA, $1 \mu \mathrm{M}$ forward and reverse primers, $0.2 \mu \mathrm{M}$ TaqMan probe, and $10 \mu \mathrm{l}$ TaqMan Universal PCR Master Mix (Applied Biosystems, Foster City, CA, USA). The PCR condition was as follows: 50 cycles of $94^{\circ} \mathrm{C}$ for $15 \mathrm{~s}$ and $60^{\circ} \mathrm{C}$ for $60 \mathrm{~s}$. The copy number of the target mRNA sequence in the starting materials was established by determining the fractional PCR threshold cycle number $(\mathrm{Ct})$ at which a fluorescence signal generated during the replication process passed above a threshold value. The initial amount of target mRNA in each sample was estimated from the Ct value with a standard curve generated using known amounts of standard plasmid DNA. Glyceraldehyde-3-phosphate dehydrogenase mRNA was also quantified as an internal control with glyceraldehyde-3-phosphate dehydrogenase control reagent (Applied Biosystems).

Genotyping of the $M D R 1$ gene

The genotype of the MDRl gene was investigated by PCRrestriction enzyme fragment length polymorphism methods. The specific primers and restriction enzymes used in this study were as previously described (Goto et al. 2002). The PCR conditions were as follows: after denaturing at $94^{\circ} \mathrm{C}$ for $3 \mathrm{~min}$, the PCR was performed with $1 \mu \mathrm{M}$ of each primer and Taq DNA polymerase (Takara, Shiga, Japan), according to the following profile: $94^{\circ} \mathrm{C}$ for $30 \mathrm{~s}, 60^{\circ} \mathrm{C}$ for $30 \mathrm{~s}$, and $72^{\circ} \mathrm{C}$ for $30 \mathrm{~s}, 35$ cycles, following by a single additional 10 -min extension at $72^{\circ} \mathrm{C}$. The PCR products were digested with or without restriction enzymes and separated on $3.5 \%$ agarose gel.

\section{Statistical analysis}

The difference in the logarithmically transformed data of MDR1 mRNA expressions between normal cortex and RCC was analyzed using Student's paired $t$-test. The correlation between the MDR1 genotype and its mRNA expression was analyzed using the MannWhitney $U$ test. $P$ values $<0.05$ were considered to be significant.

\section{Results}

Quantification of MDR1 mRNA in normal kidney cortex and renal cell carcinoma

Figure 1 shows distribution histograms of logarithmically transformed mRNA levels of MDR 1 in the normal kidney cortex and RCC segments. The average mRNA expression levels of MDR1 in the normal kidney cortex and RCC segments were 19.0 and $6.6 \mathrm{amol} / \mu \mathrm{g}$ total RNA, respectively. A statistical significant difference of the MDR1 mRNA levels in normal kidney cortex and RCC segments of each patient was observed ( $P=0.0042$, Fig. 2).

Genotype frequency of ten common SNPs of the MDRl gene in nephrectomized patients

The genotype of the $M D R l$ gene from the normal kidney cortex and RCC segments was assessed at ten common nucleotide positions in 24 Japanese patients. No differences in MDRl genotypes from both segments of each patient were found. Frequencies of the genetic variants are summarized in Table 1 . In this study, variants at exon 2-1, cDNA 61, cDNA 307, cDNA 1199, and exon $12+44$ were not observed. A variant leading to amino acid exchange was observed only at cDNA 2677. The allele frequency of the cDNA 2677 was $45.8 \%$ for allele $\mathrm{T}$ and $18.8 \%$ for allele A. At cDNA 1236 and 3435, which do not influence amino acid substitute, genetic variants were recognized. Allele frequencies were $66.7 \%$ for allele T at cDNA 1236 and $52.1 \%$ for allele T at cDNA 3435. A complete linkage was observed 

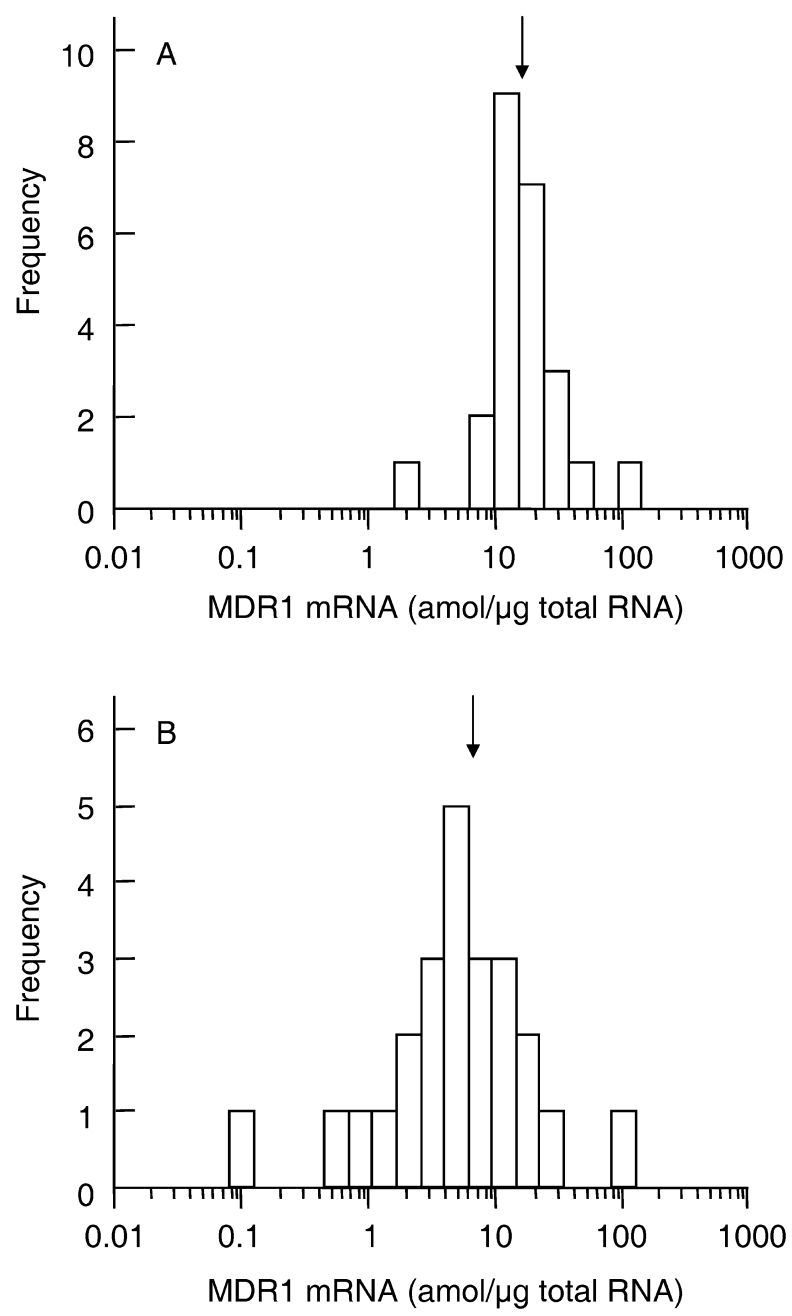

Fig. 1A, B Distribution histograms of MDR1 mRNA expression levels in normal kidney cortex (A) and renal cell carcinoma (B). MDR1 mRNA levels were logarithmically transformed to improve normality. The arrows indicate the mean values of MDR $1 \mathrm{mRNA}$ expression levels

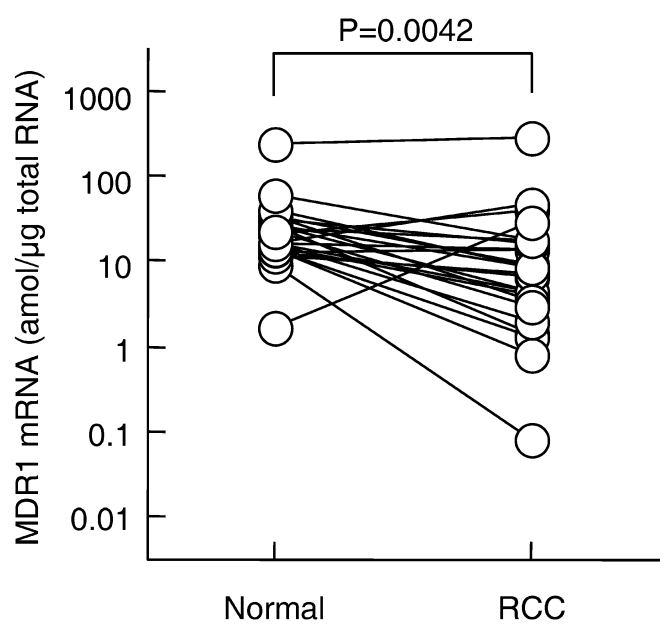

Fig. 2 Effect of malignant transformation on renal MDR1 mRNA levels in 24 patients with renal cell carcinoma between cDNA $1236 \mathrm{C} / \mathrm{T}$ and an intronic variant of exon $6+139 \mathrm{C} / \mathrm{T}$. Another intronic variant at exon $17-$ 76 was determined with the frequency of $31.3 \%$ for allele A. These allele frequencies were comparable with our previous reports in Japanese recipients of living-donor liver transplantation.

Correlation between MDRI SNPs and MDR1 mRNA expression in normal kidney cortex and renal cell carcinoma

Next, we examined the association between the $M D R I$ gene and its mRNA levels in the normal kidney cortex and RCC. As shown in Fig. 3, the significant effects of each SNP on MDR1 mRNA expression in the normal kidney cortex and RCC segments were not recognized. However, the MDR1 mRNA levels in the kidney were significantly reduced by transformation to $\mathrm{RCC}$ with $\mathrm{C} /$ $\mathrm{T}$ of cDNA 1236 and exon $6+139, \mathrm{~T} / \mathrm{A}$ and $\mathrm{T} / \mathrm{T}$ of exon 17-76, G/T of cDNA 2677, and C/T at cDNA 3435.

\section{Discussion}

In the present study, MDR1 mRNA levels in the human kidney cortex were quantified using the real-time PCR method. We previously examined its mRNA expression levels in the small intestine in Japanese recipients of living-donor liver transplantation. The MDR1 mRNA levels in the kidney cortex were about 40 -fold higher than those in the intestinal mucosa (Goto et al. 2002; Hashida et al. 2001). Even if the mucosal samples derived from patients in end-stage liver failure were considered, the MDR1 mRNA contents in the kidney cortex were markedly higher compared to the intestine. To our knowledge, this is the first study of the quantification of MDR1 mRNA level in the human kidney cortex.

It is generally accepted that the majority of administered digoxin, a cardiac glycoside, is excreted into urine and that Pgp plays an important role for its tubular secretion (Tanigawara et al. 1992). In addition, concomitant administration with various drugs, including cyclosporin A, calcium channel blockers, macrolide antibiotics, and azole antifungal drugs elevates serum concentration of digoxin, at least in part, via renal tubular Pgp (Rodin and Johnson 1988; Wakasugi et al. 1998). Considering these pharmacokinetic significances of renal Pgp, the expression levels and activity of Pgp in the kidney would be a key factor for the optimal dosage regimen of digoxin.

The present findings represent a wide interindividual variation of MDR1 mRNA levels in the human kidney cortex (about 140-fold), and no relationship between the ten common SNPs of the MDRl gene and its mRNA expression levels. It was reported that the interindividual variation of MDR1 expression also existed in the human small intestine and liver, suggesting that expression variation has been responsible for interindividual 
Table 1 MDRl genetic variants in 24 Japanese nephrectomized patients
These values are from our previous study with Japanese recipients of living-donor liver transplantation

\begin{tabular}{|c|c|c|c|c|c|c|c|}
\hline Location & Position & Allele & Effect & Frequency & Genotype & Frequency & Goto et al. ${ }^{\mathrm{a}}$ \\
\hline \multirow[t]{3}{*}{ Intron 1} & \multirow[t]{3}{*}{ Exon 2-1 } & G & \multirow[t]{3}{*}{$\begin{array}{c}\text { Initiation of } \\
\text { translation? }\end{array}$} & 100 & $\mathrm{G} / \mathrm{G}$ & 100 & 100 \\
\hline & & A & & 0 & $\mathrm{G} / \mathrm{A}$ & 0 & 0 \\
\hline & & & & & $\mathrm{A} / \mathrm{A}$ & 0 & 0 \\
\hline \multirow[t]{3}{*}{ Exon 2} & \multirow[t]{3}{*}{ cDNA 61} & A & 21 Asn & 100 & $\mathrm{~A} / \mathrm{A}$ & 100 & 100 \\
\hline & & G & $21 \mathrm{Asp}$ & 0 & $\mathrm{~A} / \mathrm{G}$ & 0 & 0 \\
\hline & & & & & $\mathrm{G} / \mathrm{G}$ & 0 & 0 \\
\hline \multirow{3}{*}{ Exon 5} & \multirow{3}{*}{ cDNA 307} & $\mathrm{~T}$ & 103 Phe & 100 & $\mathrm{~T} / \mathrm{T}$ & 100 & 100 \\
\hline & & $\mathrm{C}$ & $103 \mathrm{Leu}$ & 0 & $\mathrm{~T} / \mathrm{C}$ & 0 & 0 \\
\hline & & & & & $\mathrm{C} / \mathrm{C}$ & 0 & 0 \\
\hline \multirow[t]{3}{*}{ Intron 6} & \multirow[t]{3}{*}{ Exon $6+139$} & $\mathrm{C}$ & $?$ & 33.3 & $\mathrm{C} / \mathrm{C}$ & 8.3 & 10.3 \\
\hline & & $\mathrm{T}$ & & 66.7 & $\mathrm{C} / \mathrm{T}$ & 50 & 52.9 \\
\hline & & & & & $\mathrm{T} / \mathrm{T}$ & 41.7 & 36.8 \\
\hline \multirow[t]{3}{*}{ Exon 11} & \multirow[t]{3}{*}{ cDNA 1199} & G & $400 \mathrm{Ser}$ & 100 & $\mathrm{G} / \mathrm{G}$ & 100 & 100 \\
\hline & & A & 400 Asn & 0 & $\mathrm{G} / \mathrm{A}$ & 0 & 0 \\
\hline & & & & & $\mathrm{A} / \mathrm{A}$ & 0 & 0 \\
\hline \multirow[t]{3}{*}{ Exon 12} & \multirow[t]{3}{*}{ cDNA 1236} & $\mathrm{C}$ & Wobble & 33.3 & $\mathrm{C} / \mathrm{C}$ & 8.3 & 10.1 \\
\hline & & $\mathrm{T}$ & & 66.7 & $\mathrm{C} / \mathrm{T}$ & 50 & 49.3 \\
\hline & & & & & $\mathrm{T} / \mathrm{T}$ & 41.7 & 40.6 \\
\hline \multirow[t]{3}{*}{ Intron 12} & \multirow[t]{3}{*}{ Exon $12+44$} & $\mathrm{C}$ & $?$ & 100 & $\mathrm{C} / \mathrm{C}$ & 100 & 100 \\
\hline & & $\mathrm{T}$ & & 0 & $\mathrm{C} / \mathrm{T}$ & 0 & 0 \\
\hline & & & & & $\mathrm{T} / \mathrm{T}$ & 0 & 0 \\
\hline \multirow[t]{3}{*}{ Intron 16} & \multirow[t]{3}{*}{ Exon 17-76 } & $\mathrm{T}$ & $?$ & 68.8 & $\mathrm{~T} / \mathrm{T}$ & 45.8 & 42.6 \\
\hline & & A & & 31.3 & $\mathrm{~T} / \mathrm{A}$ & 45.8 & 51.5 \\
\hline & & & & & $\mathrm{A} / \mathrm{A}$ & 8.3 & 5.9 \\
\hline \multirow[t]{6}{*}{ Exon 21} & \multirow[t]{6}{*}{ cDNA 2677} & G & 893 Ala & 35.4 & $\mathrm{G} / \mathrm{G}$ & 0 & 22.9 \\
\hline & & $\mathrm{T}$ & 893 Ser & 45.8 & $\mathrm{G} / \mathrm{A}$ & 29.2 & 5.8 \\
\hline & & A & $893 \mathrm{Thr}$ & 18.8 & $\mathrm{G} / \mathrm{T}$ & 41.7 & 39.1 \\
\hline & & & & & $\mathrm{T} / \mathrm{A}$ & 8.3 & 15.9 \\
\hline & & & & & $\mathrm{T} / \mathrm{T}$ & 20.8 & 15.9 \\
\hline & & & & & $\mathrm{A} / \mathrm{A}$ & 0 & 1.4 \\
\hline \multirow[t]{3}{*}{ Exon 26} & \multirow[t]{3}{*}{ cDNA 3435} & $\mathrm{C}$ & Wobble & 47.9 & $\mathrm{C} / \mathrm{C}$ & 25 & 30.4 \\
\hline & & $\mathrm{T}$ & & 52.1 & $\mathrm{C} / \mathrm{T}$ & 45.8 & 50.7 \\
\hline & & & & & $\mathrm{T} / \mathrm{T}$ & 29.2 & 18.8 \\
\hline
\end{tabular}

variation of drug absorption and disposition (Goto et al. 2002; Hashida et al. 2001; Schuetz et al. 1995). A nuclear receptor, pregnane $\mathrm{X}$ receptor (termed as steroid and xenobiotic receptor), predominantly expressed in the liver and small intestine, was reported to regulate MDR1 expression in these tissues as a part of the regulatory mechanisms by various compounds including endogenous steroids and xenobiotics (Synold et al. 2001). Therefore, the nuclear receptor may contribute, at least in part, to the large interindividual variability of the expression level of MDR1 in the liver and small intestine. However, there is no information predicting the expression regulation of renal Pgp. The elucidation of the nuclear receptors and SNPs in the transcriptional regulatory region of the MDRl gene would clarify interindividual variation of renal Pgp content.

During the last few decades, the incidence of RCC has steadily increased (Chow et al. 1999). Obesity, hypertension, gender, smoking, and several drugs such as diuretics, phenacetin, and aspirin are suggested to be associated with RCC (Dhote et al. 2000). Furthermore, various genetic polymorphisms were also reported to be related to the disease (Nakamura et al. 2002; Tanaka et al. 2002). Recently, Siegsmund et al. (2002) reported that the frequency of $\mathrm{T} / \mathrm{T}$ genotype at MDR1 cDNA 3435 was significantly higher in patients with RCC than in the control Caucasians, suggesting that this SNP would be a risk factor for RCC in Caucasian. In this study, the $\mathrm{T} / \mathrm{T}$ was observed in seven of $24 \mathrm{RCC}$ patients $(29.2 \%)$. Since this frequency is not significantly different from healthy Japanese (20\%) in the data reported by Schaeffeler et al.(2001) with $x^{2}$ statistics $(P>0.540)$, the $\mathrm{T} / \mathrm{T}$ genotype at MDR1 cDNA 3435 might not be a risk factor for RCC in Japanese. Further research is needed to elucidate the association between the cDNA 3435 SNP and RCC in Japanese. Chow et al. (1999) reported the incidence of RCC in black subjects was higher than in Caucasian subjects. On the other hand, the frequency of the T/T genotype at the cDNA 3435 is reported to be markedly lower in black subjects than in Caucasian and Japanese subjects (Schaeffeler et al. 2001). The T/T frequency in black subjects with RCC should be interested. Siegsmund et al. (2002) also represented that Pgp expression levels in renal noncancerous segments were significantly lower with the $\mathrm{T} / \mathrm{T}$ genotype at cDNA 3435 than with the $\mathrm{C} / \mathrm{C}$ genotype by using the quantitative immunohistochemistry method. This suggests that renal Pgp expression levels influence susceptibility to the development of renal epithelial cancers. Our work illustrates that MDR1 levels were not affected by the cDNA $3435 \mathrm{~T} / \mathrm{T}$ genotype. In the future, not only to determine the predominant factor(s)/material(s) developing RCC but also to clarify its renal handling, including the contribution of Pgp, are necessary for 


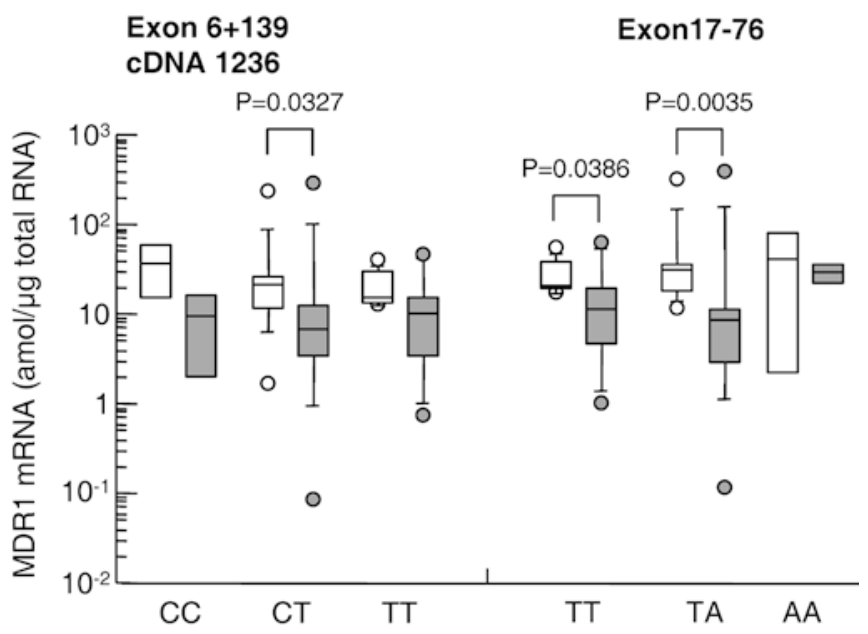

cDNA 2677

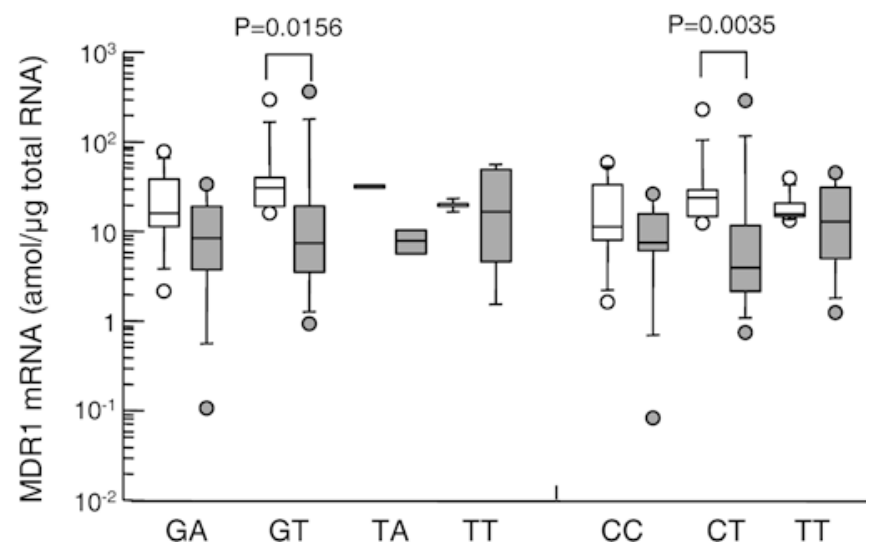

Fig. 3 Comparison of mRNA levels in the normal kidney cortex, renal cell carcinoma (RCC) segments, or their variation by carcinogenesis with the MDRl genotype. The MDR1 mRNA levels in the normal kidney cortex (open box) and RCC segments (gray box) were compared with the five polymorphic SNPs. Simultaneously, the variation of the expression levels of MDR1 mRNA were assessed in comparison with the $M D R I$ genotypes between normal and RCC segments. After statistical analyses by Mann-Whitney $U$ test, $P$ values less than 0.05 were shown

analysis of the relationship between RCC and the SNP of the $M D R I$ gene.

RCC displays an intrinsically high degree of resistance to chemotherapy (Hartmann and Bokemeyer 1999). Fojo et al. (1987) and Kakehi et al. (1988) represented that the resistance of RCC against anticancer drug vinblastine was associated with MDR1 expression using cell lines. The present study clarified that MDR1 expression levels showed a downward tendency by malignant transformation to RCC and that expression in the RCC was still relatively high. These results are compatible with other groups (Fojo et al. 1987; Kakehi et al. 1988). Taken together with the fact that various anticancer drugs are substrates of Pgp, it is suggested that this phenomenon is, at least in part, involved in the chemoresistance of RCC. The downregulation of MDR1 mRNA in the kidney cortex by transformation to RCC was dependent on the $\mathrm{T}$ allele at exon 17-76
(Fig. 3). Despite the small number of patients carrying the A/A genotype at exon 17-76 $(n=2)$, the mRNA expression of MDR1 in the kidney might be downregulated by carcinogenesis in patients with the $\mathrm{T}$ allele. Therefore, further studies would clarify the effect of SNPs in the MDRl gene on the reducing rate of its mRNA level in renal tissue by carcinogenesis. In addition to MDR1, glutathione S-transferase, topoisomerase II, and MDR-associated protein are suggested to contribute to the chemoresistance of RCC (Volm et al. 1993; Kim et al. 1996). Elucidation of not only renal handling of anticancer agents but also function and expression levels of these proteins in RCC, and of their relations with SNPs, give information for the adequate selection of anticancer agents for individual RCC.

In summary, we estimated the copy number of MDR 1 mRNA in the human kidney cortex and RCC and found that there is a wide interindividual variation in renal MDR1 expression levels and that MDR1 mRNA levels tend to decrease by malignant transformation to RCC in the human kidney. In addition, the ten common polymorphisms of the MDRl gene were examined, and the effect of SNPs on expression levels of the transporter mRNA was not observed in the normal kidney cortex and RCC. To our knowledge, this is the first report representing the measurement of renal MDR1 mRNA and correlation of the expression and SNPs of MDRl.

Acknowledgements This work was supported by a grant-in-aid for Research on Human Genome, Tissue Engineering, and Food Biotechnology from the Ministry of Health, Labor, and Welfare of Japan (H12-Genome-019), a grant-in-aid for Scientific Research from the Ministry of Education, Culture, Sports, Science, and Technology of Japan, and the 21st Century COE Program "Knowledge Information Infrastructure for Genome Science". M.G. is supported as a Research Assistant by the 21st Century COE Program "Knowledge Information Infrastructure for Genome Science".

\section{References}

Ambudkar SV, Dey S, Hrycyna CA, Ramachandra M, Pastan I, Gottesman MM (1999) Biochemical, cellular, and pharmacological aspects of the multidrug transporter. Annu Rev Pharmacol Toxicol 39:361-398

Chow WH, Devesa SS, Warren JL, Fraumeni, JF Jr (1999) Rising incidence of renal cell cancer in the United States. JAMA 281:1628-1631

Dhote R, Pellicer-Coeuret M, Thiounn N, Debre B, Vidal-Trecan G (2000) Risk factors for adult renal cell carcinoma: a systematic review and implications for prevention. BJU Int 86:20-27

Fojo AT, Shen DW, Mickley LA, Pastan I, Gottesman MM (1987) Intrinsic drug resistance in human kidney cancer is associated with expression of a human multidrug-resistance gene. J Clin Oncol 5:1922-1927

Gerloff T, Schaefer M, Johne A, Oselin K, Meisel C, Cascorbi I, Roots I (2002) MDR1 genotypes do not influence the absorption of a single oral dose of $1 \mathrm{mg}$ digoxin in healthy white males. Br J Clin Pharmacol 54:610-616

Goto M, Masuda S, Saito H, Uemoto S, Kikuchi T, Tanaka K, Inui $\mathrm{K}$ (2002) C3435T polymorphism in the MDRl gene affects the enterocyte expression level of CYP3A4 rather than Pgp in recipients of living-donor liver transplantation. Pharmacogenetics 12:451-457 
Hartmann JT, Bokemeyer C (1999) Chemotherapy for renal cell carcinoma. Anticancer Res 19:1541-1544

Hashida T, Masuda S, Uemoto S, Saito H, Tanaka K, Inui K (2001) Pharmacokinetic and prognostic significance of intestinal MDR1 expression in recipients of living-donor liver transplantation. Clin Pharmacol Ther 69:308-316

Hoffmeyer S, Burk O, von Richter O, Arnold HP, Brockmoller J, Johne A, Cascorbi I, Gerloff T, Roots I, Eichelbaum M, Brinkmann U (2000) Functional polymorphisms of the human multidrug-resistance gene: multiple sequence variations and correlation of one allele with P-glycoprotein expression and activity in vivo. Proc Natl Acad Sci 97:3473-3478

Kakehi Y, Kanamaru H, Yoshida O, Ohkubo H, Nakanishi S, Gottesman MM, Pastan I (1988) Measurement of multidrugresistance messenger RNA in urogenital cancers; elevated expression in renal cell carcinoma is associated with intrinsic drug resistance. J Urol 139:862-865

Kim WJ, Kakehi Y, Kinoshita H, Arao S, Fukumoto M, Yashida O (1996) Expression patterns of multidrug-resistance (MDR1), multidrug resistance-associated protein (MRP), glutathione-Stransferase- $\pi$ (GST- $\pi$ and DNA topoisomerase II (TOPO II) genes in renal cell carcinomas and normal kidney. J Urol 156:506-511

Kim RB, Leake BF, Choo EF, Dresser GK, Kubba SV, Schwarz UI, Taylor A, Xie HG, McKinsey J, Zhou S, Lan LB, Schuetz JD, Schuetz EG, Wilkinson GR (2001) Identification of functionally variant $M D R 1$ alleles among European Americans and African Americans. Clin Pharmacol Ther 70:189-199

Kurata Y, Ieiri I, Kimura M, Morita T, Irie S, Urae A, Ohdo S, Ohtani H, Sawada Y, Higuchi S, Otsubo K (2002) Role of human MDRl gene polymorphism in bioavailability and interaction of digoxin, a substrate of P-glycoprotein. Clin Pharmacol Ther 72:209-219

Motohashi H, Sakurai Y, Saito H, Masuda S, Urakami Y, Goto M, Fukatsu A, Ogawa O, Inui K (2002) Gene expression levels and immunolocalization of organic ion transporters in the human kidney. J Am Soc Nephrol 13:866-874

Nakamura E, Megumi Y, Kobayashi T, Kamoto T, Ishitoya S, Terachi T, Tachibana M, Matsushiro H, Habuchi T, Kakehi Y,
Ogawa O (2002) Genetic polymorphisms of the interleukin-4 receptor $\alpha$ gene are associated with an increasing risk and a poor prognosis of sporadic renal cell carcinoma in a Japanese population. Clin Cancer Res 8:2620-2625

Rodin SM, Johnson BF (1988) Pharmacokinetic interactions with digoxin. Clin Pharmacokinet 15:227-244

Schaeffeler E, Eichelbaum M, Brinkmann U, Penger A, AsantePoku S, Zanger UM, Schwab M (2001) Frequency of C3435T polymorphism of MDRl gene in African people. Lancet 358:383-384

Schuetz EG, Furuya KN, Schuetz JD (1995) Interindividual variation in expression of P-glycoprotein in normal human liver and secondary hepatic neoplasms. J Pharmacol Exp Ther 275:1011-1018

Siegsmund M, Brinkmann U, Schaffeler E, Weirich G, Schwab M, Eichelbaum M, Fritz P, Burk O, Decker J, Alken P, Rothenpieler U, Kerb R, Hoffmeyer S, Brauch H (2002) Association of the P-glycoprotein transporter $M D R 1^{C 3435 T}$ polymorphism with the susceptibility to renal epithelial tumors. J Am Soc Nephrol 13:1847-1854

Synold TW, Dussault I, Forman BM (2001) The orphan nuclear receptor SXR coordinately regulates drug metabolism and efflux. Nat Med 7:584-590

Tanaka Y, Sasaki M, Kaneuchi M, Fujimoto S, Dahiya R (2002) Single nucleotide polymorphisms of estrogen receptor $\alpha$ in human renal cell carcinoma. Biochem Biophys Res Commun 296:1200-1206

Tanigawara Y, Okamura N, Hirai M, Yasuhara M, Ueda K, Kioka N, Komano T, Hori R (1992) Transport of digoxin by human P-glycoprotein expressed in a porcine kidney epithelial cell line $\left(\right.$ LLC-PK $\left._{1}\right)$. J Pharmacol Exp Ther 263:840-845

Volm M, Kastel M, Mattern J, Efferth T (1993) Expression of resistance factors (P-glycoprotein, glutathione S-transferase- $\pi$, and topoisomerase II) and their interrelationship to proto-oncogene products in renal cell carcinomas. Cancer 71:3981-3987

Wakasugi H, Yano I, Ito T, Hashida T, Futami T, Nohara R, Sasayama S, Inui K (1998) Effect of clarithromycin on renal excretion of digoxin: interaction with P-glycoprotein. Clin Pharmacol Ther 64:123-128 